\title{
Is this the last stand of the Critically Endangered green sawfish Pristis zijsron in the Arabian Gulf?
}

\author{
Rima W. Jabado*, Reem A. Al Baharna, Sultan R. Al Ali, Khalfan O. Al Suwaidi, \\ Ayesha Y. Al Blooshi, Shaikha S. Al Dhaheri
}

Terrestrial and Marine Biodiversity Sector, Environment Agency - Abu Dhabi, Abu Dhabi, United Arab Emirates

\begin{abstract}
The sawfishes (Pristidae) represent one of the most threatened groups of marine fish around the world. Between October 2015 and June 2016, interviews $(\mathrm{n}=82)$ were conducted to assess the occurrence of sawfish in United Arab Emirates waters and gain insight from fishers' traditional ecological knowledge regarding the status, uses, and cultural significance of sawfish. Almost all respondents $(95.1 \%$ ) had previously seen a sawfish, and $92.6 \%$ confirmed that their numbers had declined in the last $20 \mathrm{yr}$. Most respondents reported encounters in the last 5 to $10 \mathrm{yr}$, with $18.3 \%(n=15)$ having seen a sawfish in the last $2 \mathrm{yr}$. Sawfish were not perceived as a culturally significant resource $(76.8 \%)$ and when caught were primarily used as food, their high-value fins sold to traders, and rostra retained as decorations. The consensus was that while sawfish were previously targeted, they are now caught primarily as bycatch in gill nets. Based on pictures and rostra encountered $(\mathrm{n}=19)$, it appears that the green sawfish Pristis zijsron is more common in United Arab Emirates waters than the narrow sawfish Anoxypristis cuspidata, which is likely to be present off the Ras $\mathrm{Al}$ Khaimah coast. While the results of this study provide evidence of a large decline in sawfish, they hint at the possible importance of Abu Dhabi waters as a region where sawfish are still encountered and where research and monitoring, as well as conservation and recovery efforts, should be focused to avoid local extinction and recover their populations.
\end{abstract}

KEY WORDS: United Arab Emirates · Fishermen · Interviews • Pristidae • Conservation • Traditional ecological knowledge

\section{INTRODUCTION}

The sawfishes (Pristidae) are considered among the most endangered marine fish in the world and are believed to be extinct throughout much of their historical range (Dulvy et al. 2014). Information on pristid biology and life history remains limited (Morgan et al. 2015); however, they share the same characteristics as many other large cartilaginous fishes, including long gestation periods, live birth with often large offspring, late sexual maturity, long lifespans, and intermittent breeding (Simpfendorfer 2000). Sawfish usually inhabit estuaries and other inshore waters, exposing them to multiple pressures resulting

\footnotetext{
*Corresponding author: rima.jabado@ead.ae
}

from coastal development, declining water quality, habitat destruction and degradation, climate change, and incidental capture in artisanal commercial and recreational fisheries (Seitz \& Poulakis 2006, Peverell 2009). These life history traits and their high habitat and trophic specificity, along with their morphology and foraging behavior, predispose them to incidental capture in coastal fishing nets (Simpfendorfer 2000, Seitz \& Poulakis 2006, Stevens et al. 2008, Peverell 2009, Dulvy et al. 2014). Furthermore, while overfishing, both intentional and as bycatch, is thought to be the primary reason for declines in sawfish numbers worldwide, sawfishes have more recently been targeted for the fin trade industry (Robillard \& Séret 2006).

() The authors 2017. Open Access under Creative Commons by Attribution Licence. Use, distribution and reproduction are unrestricted. Authors and original publication must be credited. 
The available data for the Arabian Gulf region overwhelmingly suggest that sawfish were historically abundant but are currently rarely encountered, with suggestions that they are now extinct as a functional component of regional coastal ecosystems (Moore 2015). Two species, the green sawfish Pristis zijsron and narrow sawfish Anoxypristis cuspidata, have historically been present in this body of water (Faria et al. 2013, Moore 2015). The green sawfish is believed to occur only along the coasts of the United Arab Emirates (UAE), Qatar, Saudi Arabia, and Kuwait, while the narrow sawfish likely only occurs along the Iraqi and Iranian coasts. These species are listed as Critically Endangered and Endangered, respectively, on the IUCN Red List, and are also listed in Appendix I of the Convention on International Trade in Endangered Species of Flora and Fauna (CITES), prohibiting international commercial trade in sawfish specimens or their products (D'Anastasi et al. 2013, Simpfendorfer 2013).

Fisheries in the UAE are artisanal and typically multi-species and multi-gear (Grandcourt 2012, Jabado et al. 2015a). Fishers operate 2 types of boats: small fiberglass dories ('tarad') and traditional wooden dhows ('lansh') with the primary fishing gear including drift nets, gill nets, hand lines, traps, longlines, and trolls (Grandcourt 2012, Jabado et al. 2015a). During a comprehensive fishery-dependent study of elasmobranchs in the UAE between 2010 and 2012 (Jabado et al. 2015b), only 1 sawfish (green sawfish) specimen was encountered at the Al Jubail landing site in Sharjah (R. Jabado unpubl. data). However, informal discussions and interviews with fishers across the country have suggested their continued occurrence in certain areas offshore of Dubai and in coastal Abu Dhabi waters, especially around the Marawah Marine Biosphere Reserve (Jabado et al. 2015a). Furthermore, citizen science reports submitted to the Gulf Elasmo Project between 2011 and 2016 photographically confirmed 5 encounters with green sawfish in Abu Dhabi, Dibba, and Sharjah (www.gulfelasmoproject.com; R. Jabado unpubl. data). However, most of the information on sawfish occurrence and distribution in the UAE remains anecdotal. Because of their current status around the world (Dulvy et al. 2016), it is essential to gather upto-date information on the presence, abundance, and distribution of sawfish in UAE waters and assess to what extent these species might still occur.

Engaging with fishers to collect traditional ecological knowledge (TEK) is now a well-established area of social and ecological research (Johannes et al. 2000, Sáenz-Arroyo et al. 2005, Giglio et al. 2015).
Studies focusing on the TEK of fishermen can provide valuable baseline data, which can be used to direct scientific studies, particularly in situations where information is scarce or lacking, and can also provide insight into local attitudes towards species of interest (Johannes et al. 2000). This method is being increasingly used to gain a better understanding of sawfish in data-poor areas as well as to inform science and management (Robillard \& Séret 2006, Norton et al. 2012, Hossain et al. 2015, Leeney 2015, Leeney \& Poncelet 2015, Dulvy et al. 2016, Reis-Filho et al. 2016). For example, data collected from sawfish encounters in the USA have provided baseline information for the identification of critical habitats and nursery hotspots, as well as seasonal movements (Seitz \& Poulakis 2002, Poulakis \& Seitz 2004, Norton et al. 2012). Due to the absence of data on the status, distribution, abundance, and cultural significance of sawfish in the UAE, it is crucial to use the ecological knowledge of Emirati fishers to guide research and conservation. Even though sawfish have been granted complete legal protection in the UAE since 2008 (MOCCAE 2014, Jabado et al. 2015a), this is particularly important, since populations of these species require strict conservation actions and a considerable time frame to recover (Dulvy et al. 2016).

By interviewing fishers in the UAE, we aimed to (1) assess whether sawfish still occur in UAE waters, and if so, where remnant populations of each species are most likely to be encountered; (2) identify the threats and gear types responsible for sawfish catches; (3) gain insight on fishers' TEK of sawfish; (4) document traditional values associated with these species including their cultural significance; and (5) identify and recommend research and conservation actions required in the UAE to ensure the recovery and longterm survival of this unique group of elasmobranchs in the Arabian Gulf.

\section{MATERIALS AND METHODS}

In-person interviews were conducted between October 2015 and June 2016 at various landing sites and fishers' majlis (gathering halls) in the UAE (Fig. 1). The first 4 authors completed all interviews. At each location, interviewers introduced themselves and explained that the team wished to conduct a short interview on a fish species. Typically, between 3 and 10 fishers were encountered at the various locations for a short period prior to the morning or evening prayers. Individuals present at these sites during visits were randomly chosen, taken aside, and 


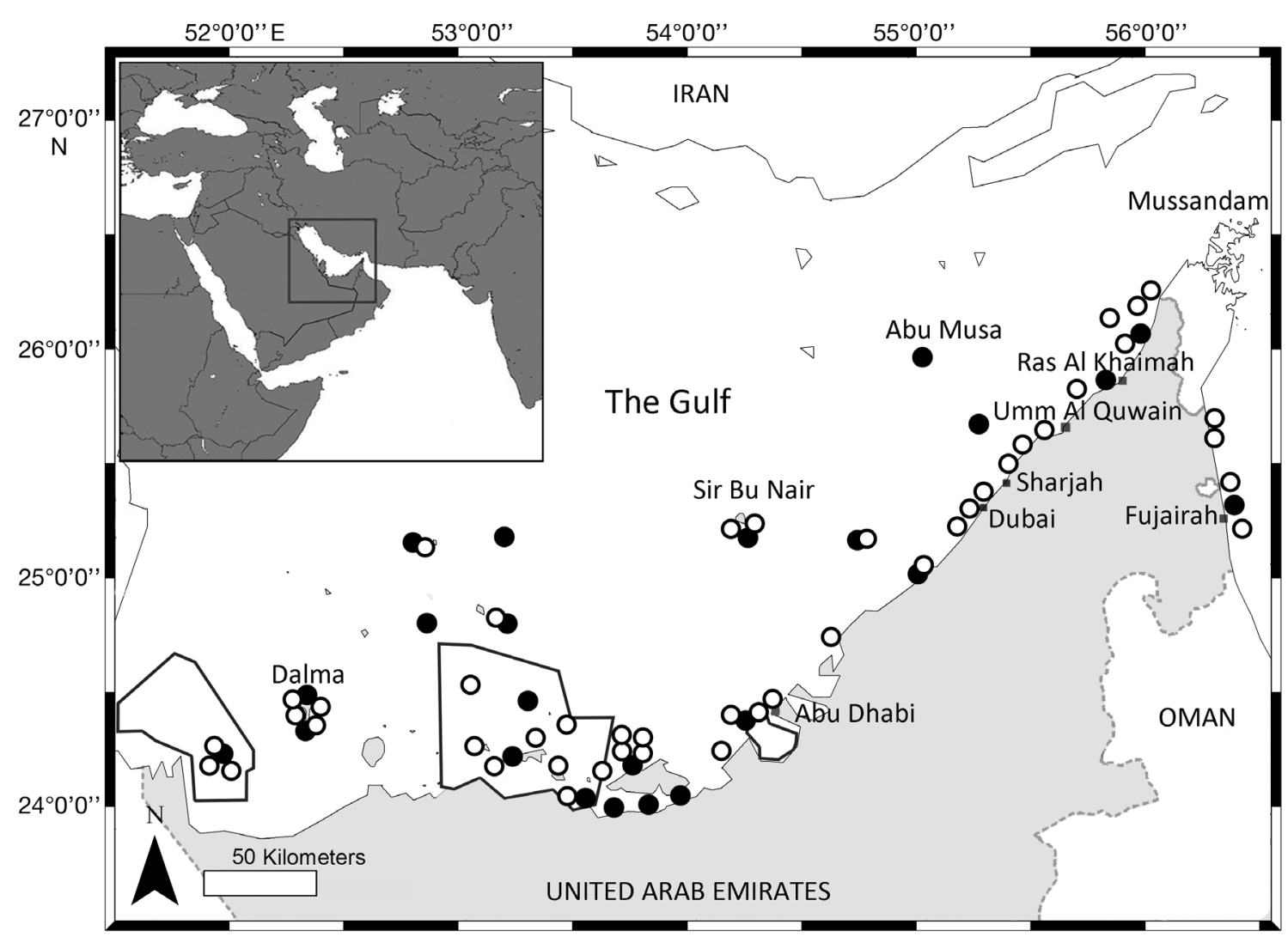

Fig. 1. United Arab Emirates, indicating sites highlighted by fishers as areas where sawfish (Pristidae) had previously been caught or seen (open circles) and where they can still be encountered (closed circles). The demarcations indicate declared Marine Protected Areas in Abu Dhabi waters (Al Yasat on the western border, Marawah Marine Biosphere Reserve in the center, and Bu Sayayeef closer to Abu Dhabi city)

shown a picture of a sawfish (laminated color illustration of the green sawfish Pristis zijsron) to determine if they recognized the animal. One-to-one interviews proceeded only if individuals were able to name the animal, and although guided by a series of questions (the complete questionnaire is available in the Supplement at www.int-res.com/articles/n032p265_ supp.pdf), they were conducted in a conversational manner. Each interview took approximately 10 to 15 min to complete, depending on the information provided by the respondents. Interviews focused on fishers but on a few occasions, fish auctioneers or traders were also interviewed.

The questionnaire was adapted from Leeney \& Poncelet (2015) and translated into Arabic. The standard semi-structured questionnaire contained both open-ended and closed questions. It was designed to collect basic background information on the respondent, fishing characteristics (e.g. boat, crew numbers, fishing gear types), details of past and/or recent sightings and captures of sawfish (including estimated total length including the rostrum, location, and date), spatial and temporal patterns of occurrence over time (locations and seasons), gear types known to capture sawfish, traditional and current uses, value of various sawfish products, cultural importance of this species, and the availability of sawfish rostra that the team could photograph and measure. A map of the marine region in which the interviews were being carried out was included with each questionnaire, and respondents were asked to indicate on the map sites where sawfish had previously been caught and areas where they thought sawfish might still occur. Even though interviews were conducted with each fisher separately, to ensure the reliability of the information provided, only areas that were highlighted by at least 4 respondents as locations where sawfish persist are reflected in Fig. 1.

Data were analyzed qualitatively, with some results requiring the creation of binned categories (i.e. age of respondents and dates where respondents had last seen a sawfish). Seasons were defined as autumn (September to November), winter (December to Feb- 
ruary), spring (March to May), and summer (June to August). Although the location data of encounters reported were plotted on a map, it was noticeable that few fishers could pinpoint exact catch locations and instead provided locations based on bearings around an area or island (north, south, east, west), including water depth.

During interviews, observed rostra at the various sites were measured and photographed with species identified based on Faria et al. (2013). The limited sample size did not allow for any detailed analyses.

\section{RESULTS}

\section{Fisher profiles}

Individuals interviewed were Emirati males and all recognized the illustration of the green sawfish Pristis zijsron. A total of 82 interviews were completed in Abu Dhabi $(n=35)$, Dubai $(n=11)$, Sharjah $(n=9)$, Umm Al Quwain ( $\mathrm{n}=3)$, Ras Al Khaimah $(\mathrm{n}=14)$, and Fujairah ( $\mathrm{n}=10)$, and $95.1 \%$ of the respondents $(n=78)$ had seen at least 1 sawfish during their lifetime.

Respondents were aged between 23 and over $80 \mathrm{yr}$ (some fishers did not recollect their exact birth date but stated they were over 80 yr old), with $29.2 \%$ aged between 50 and 59 while $48.7 \%$ were over $60 \mathrm{yr}$ old (Fig. 2). All respondents were involved in fishing, with 44 active commercial fishers $(53.6 \%), 31$ retired commercial fishers $(37.8 \%), 6$ recreational fishers $(7.3 \%)$, and 1 fish auctioneer. Forty-two of the commercially active or retired respondents also had other occupations which included fish trading or auctioning $(\mathrm{n}=10)$, while the remainder were employed by the government. All respondents stated that they had started fishing as children as early as $4 \mathrm{yr}$ old with

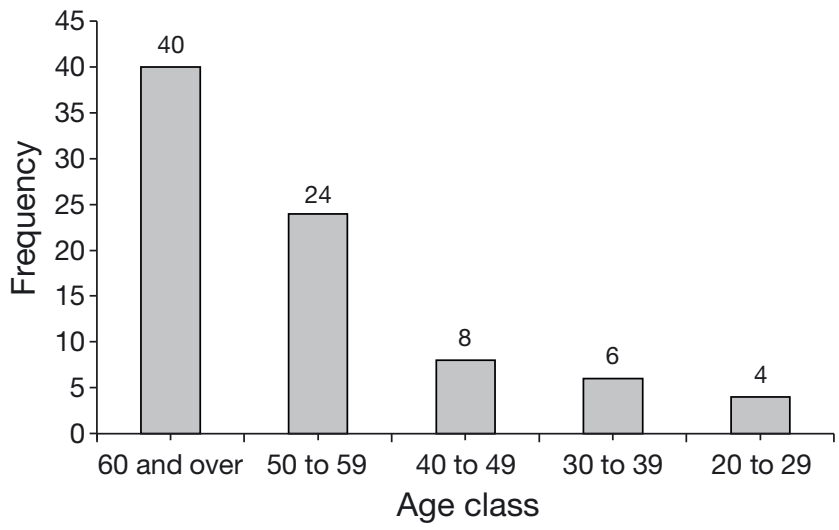

Fig. 2. Age class distribution of respondents $(n=82)$, indicating the number of fishers interviewed in each age class their fathers and relatives, with $75.6 \%(\mathrm{n}=62)$ of them having more than $40 \mathrm{yr}$ of fishing experience. The 4 respondents who had not seen a sawfish were aged between 50 and $59(\mathrm{n}=3)$ and over $60 \mathrm{yr}(\mathrm{n}=1)$.

Fishers were either boat owners $(46.3 \%)$ or both owners and captains of their fishing vessels $(47.5 \%)$. The majority used a fiberglass dory ('tarad') as their primary fishing boat $(74.3 \% ; \mathrm{n}=61)$, while only 9 individuals $(10.9 \%)$ operated traditional dhows ('lansh'). Ten respondents had multiple boats of both types, while 2 individuals did not own boats and worked on family-owned boats as crew.

\section{Trends in sawfish encounters and habitat preferences}

Different vernacular names were used to identify sawfish, with the majority of respondents $(82.9 \%)$ referring to it as 'Sayaf' or 'Sayafa' (meaning 'the one with a sword') but with other slight variations of local names including 'Bu Minshar' (meaning 'father of the saw'), 'Saif Sayaf,' and 'Abu Saif.' Furthermore, a few individuals $(n=6)$ mentioned that juvenile sawfish were referred to as 'Blindo.'

A high proportion of the respondents that had encountered sawfish $(\mathrm{n}=78)$ had seen them either alive $(10.2 \%)$, dead $(10.2 \%)$, or both dead and alive $(79.4 \%)$. Of these, $38.4 \%(n=30)$ had seen a sawfish in the last $6 \mathrm{yr}$, and 6 individuals $(7.6 \%)$ indicated they had seen a sawfish within the last year (Fig. 3). Specifically, 2 fishers mentioned they had seen a sawfish at the Sharjah landing site 3 months prior to the interviews (March 2016), and 1 fisher in Abu Dhabi stated he had caught 3 in March in the same fishing area. Of those respondents that had seen a sawfish in their lifetime, 5 individuals over $60 \mathrm{yr}$ old believed they had seen over 100. However, the majority of respondents $(51.3 \%)$ had seen 10 or fewer in their lifetime.

The estimated size ranges of sawfish encountered varied between $<1$ to $>6 \mathrm{~m}$ in estimated total length. When considering published size at maturity information for the green sawfish, which shows that the mean size at birth is $76 \mathrm{~cm}$ in total length and size at maturity is between 340 and $380 \mathrm{~cm}$ in total length (Peverell 2009, Simpfendorfer 2013), all life stages were encountered by fishers. Most respondents indicated that animals of $2-3 \mathrm{~m}(33.3 \%, \mathrm{n}=26)$ and $3-4 \mathrm{~m}(29.4 \%, \mathrm{n}=23)$ were most common. Two individuals described animals of $>6 \mathrm{~m}$ in length with rostra that reached $1.5 \mathrm{~m}$, while 4 individuals highlighted that a range of sizes were found depending 


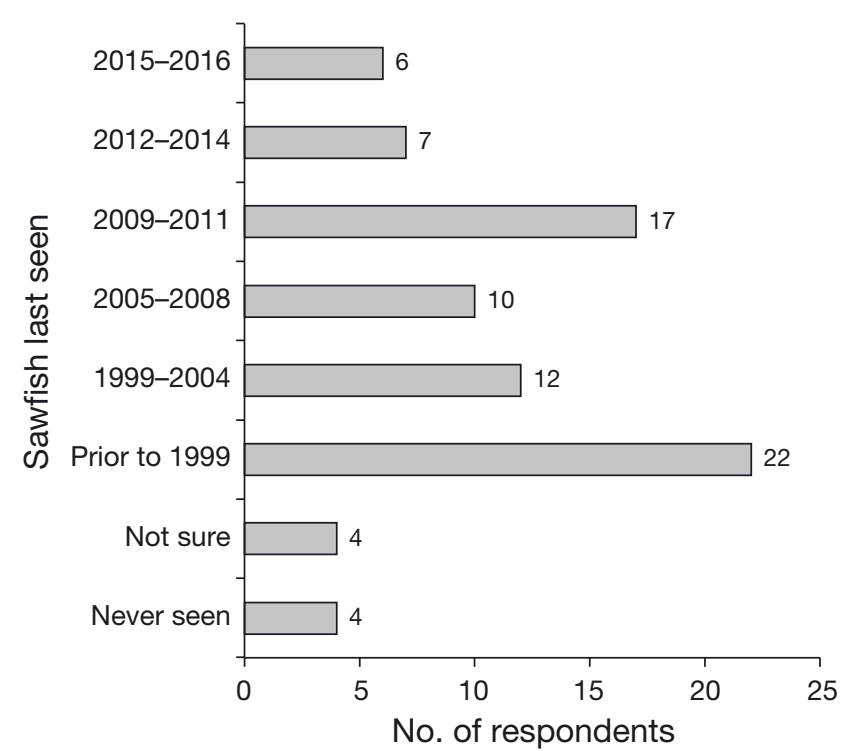

Fig. 3. Time periods within which respondents had last seen a sawfish

on the time of the year. When asked about the seasonal occurrence of sawfish, most individuals provided a range of seasons (i.e. winter to summer). Only 1 respondent mentioned autumn (early September) as the best time of the year to see sawfish, while 4 respondents stated they could be encountered throughout the year. The remaining $93.3 \%$ ( $\mathrm{n}=$ 77) of individuals highlighted the winter, spring, and summer seasons. When probed to provide more details, $70.7 \%$ of these respondents mentioned the months from February to May as the peak season. One fisherman also stated that pearl divers used to call the early months of spring, when the weather was cloudy, 'youlad sayafa,' meaning 'sawfish are being born,' highlighting their prevalence during this time of the year. Three respondents recalled wading in shallow waters in spring and early summer when adult male and female sawfish could be found together so they could harpoon them both. These same individuals stated that sawfish could be caught in high numbers in the same area with up to 12 (likely young of year and large juveniles ranging between 1 and $3 \mathrm{~m}$ ) caught in 1 net. Finally, 5 respondents commented on females giving birth in the early summer with young present in shallow Abu Dhabi waters at that time of the year.

Approximately $52.4 \%(n=43)$ of respondents perceived the preferred habitat to be inshore with sandy patches and seagrass beds as being the main areas in which sawfish, especially juveniles, occurred. Another $29.2 \%(n=24)$ of individuals considered offshore deep-water habitats of $30-70 \mathrm{~m}$ as being the preferred habitats and where the largest sawfish occurred (likely adults). Of these respondents, 83.3\% fished in the deeper waters of Ras Al Khaimah, Sharjah, and Fujairah (Sea of Oman).

According to all of the fishers interviewed, sawfish catches were a regular occurrence about $20 \mathrm{yr}$ ago, with 1 or 2 individuals often caught together in a net $(46.1 \%, \mathrm{n}=36)$. Respondents were able to indicate areas where they had previously caught or seen sawfish on a map of UAE waters provided (Fig. 1). Areas were mainly highlighted by providing references to islands, bearings, or water depths around certain fishing sites. Many described the widespread occurrence of sawfish in certain locations and suggested that the island of ' $\mathrm{Bu}$ Sayayeef' (meaning 'father of saws') around Abu Dhabi city was named due to the abundance of these animals in the shallow waters surrounding it. Furthermore, participants were asked to indicate areas where sawfish most likely persist or could still be found (Fig. 1). For the current occurrence of sawfish, respondents indicated fewer areas but most frequently referred to Dalma Island (Abu Dhabi), Sir Bu Nair Island (Sharjah), Mirfa, and the shallow coastal waters of Abu Dhabi close to the Marawah Marine Biosphere Reserve. Furthermore, 6 fishers in Abu Dhabi stated there were areas they could take the interviewers where sawfish were highly likely to be seen in the spring.

\section{Status and threats}

In total, $92.6 \%(\mathrm{n}=76)$ of respondents stated they had seen a declining trend in the number of sawfish. These respondents believed that changes had begun 5 yr ago (23\%), 10 yr ago (26.9\%), and between 15 and 20 yr ago (33.3\%) respectively. Three individuals $(3.6 \%)$ were not sure whether any changes had taken place, highlighting they were either retired and no longer out at sea fishing $(\mathrm{n}=2)$ or worked mainly with traps now, a gear that did not allow interactions with these species. Two individuals $(2.4 \%)$ stated there were no changes, while 1 respondent indicated they were increasing because of their protected status. When asked about the causes of this decline, fishers provided a range of responses, with some suggesting more than 1 potential cause. The most frequent causes mentioned included 'too many people fishing and too many laborers,' 'mechanized vessels and fishing by foreign fishers in UAE waters,' and 'destructive fishing gear and the change in the coastline.' Answers were categorized based on the overall issues highlighted. As such, the most common perceived causes of sawfish declines were overfish- 
ing (all gear combined) followed by the use of all types of fishing nets (Table 1), with fishers emphasizing that sawfish entangled easily in gill nets due to their rostra. Older fishers (those 60 and over) stated that nets were the main cause of decline and made it easy to catch sawfish but that in the past, harpoons or spears were used to target this species. Respondents were able to define the various gear types that typically caught sawfish, with $69.2 \%(\mathrm{n}=56)$ describing various net types (including barrier nets ['Al Sakar'], drift nets ['Hayal'], and gill nets ['Ghazal' and 'Leikh']), while the remaining individuals mentioned hooks $(16.6 \%)$ or harpoons $(5.1 \%)$.

\section{Uses of sawfish products}

The majority of respondents $(76.8 \%)$ stated that sawfish have no cultural value (defined in terms of religious or spiritual connections) in the UAE. Those that believed sawfish had value $(\mathrm{n}=18)$ mentioned the tradition of using sawfish meat as a source of food $(\mathrm{n}=14)$, livers for extracting oil and using it in traditional boat building $(n=2)$, or for the display of saws as decorations in homes and museums $(\mathrm{n}=2)$. Yet, all respondents listed several traditional uses for the various sawfish body parts. The meat was highly regarded as a food source and often dried $(46.4 \%$ of respondents). However, some fishers highlighted its use in a traditional Emirati dish called 'Gisheet' (with the flesh boiled with mixed spices, drained, and then sautéed with onions, ginger, garlic, and ground spices to then be served with steamed white rice and sprinkled with lemon). Other fishers (9.7\%) also recalled targeting sawfish in the past to remove eggs from pregnant females, which were also dried for food. The liver oil (17.1\%) was mainly used for waterproofing the traditional dhow vessels, although a few fishers $(6.2 \%)$ told stories of the oil extracted from juveniles being mixed with flour to bake special medic-

Table 1. Perceived causes of the changes in sawfish (Pristidae) abundance as a percentage of all respondents $(\mathrm{N})$ stating a decline in sawfish numbers $(\mathrm{n}=80)$

\begin{tabular}{|lrr|}
\hline Perceived cause & N & $\%$ \\
\hline Overfishing & 37 & 46.2 \\
Fishing nets & 21 & 26.2 \\
Coastal development and pollution & 8 & 10.0 \\
Hooks and demersal longlines & 2 & 2.5 \\
Climate change & 1 & 1.2 \\
Fin trade & 1 & 1.2 \\
Did not know & 10 & 12.5 \\
\hline
\end{tabular}

inal bread that helped with digestion and stomach complaints. This bread could be stored for months (preserved with salt and the liver oil), and was often shared with neighbors. All respondents described rostra as used mainly for decoration in houses, frequently given to museums, or placed at the entrance to houses as 'barbed wire' for protection, with the sharp rostral teeth acting as a deterrent to intruders. One fisherman told a story of how he would use his rostra to make sure his children went to bed at night. Most fishers (76.8\%) also mentioned the demand for shark fins from Asia for the preparation of soup adding that fin traders would visit markets in the UAE to purchase these. Fishers stated that there had been traders looking to purchase the fins of sawfish up to 20 yr ago. However, several individuals (12.4\%) also mentioned the 'needles' (ceratotrichia) in the fins being used for stitching in operations and surgical procedures, although this could not be confirmed.

Respondents were generally not aware of the actual prices that various sawfish parts could fetch, as animals, for the most part (82.9\% of respondents), have been sold whole to traders over the last $15 \mathrm{yr}$. Sawfish fins were considered most valuable after those from guitarfish, with prices having gone up in the past $10 \mathrm{yr}$ in 2016, they could fetch prices between US\$175 and $\$ 800 \mathrm{~kg}^{-1}$ of fresh fins, depending on their size. Those individuals $(n=21)$ that provided prices for the whole animal stated it could currently sell for between US\$300 and $\$ 2000$, depending on its size. The remaining fishers retained the saw and the meat but sold the fins to traders.

\section{Observed rostra}

A total of 19 rostra from 2 species, ranging from 64 to $133 \mathrm{~cm}$ in length, were observed, of which 18 belonged to the green sawfish and 1 to the narrow sawfish Anoxypristis cuspidata (Fig. 4, Table 2). These rostra were all dried and used as decorations in fishers' cooperatives $(n=3)$, private collections $(n=$ $13)$, or given as gifts to the interviewers $(n=3)$. Capture location data, dates, and sex of the animals the rostra came from were not available from the fishers, but all confirmed that they originated from specimens caught in UAE waters.

\section{DISCUSSION}

This is the first study focusing on TEK of sawfish in the Arabian Gulf region and provides a baseline 

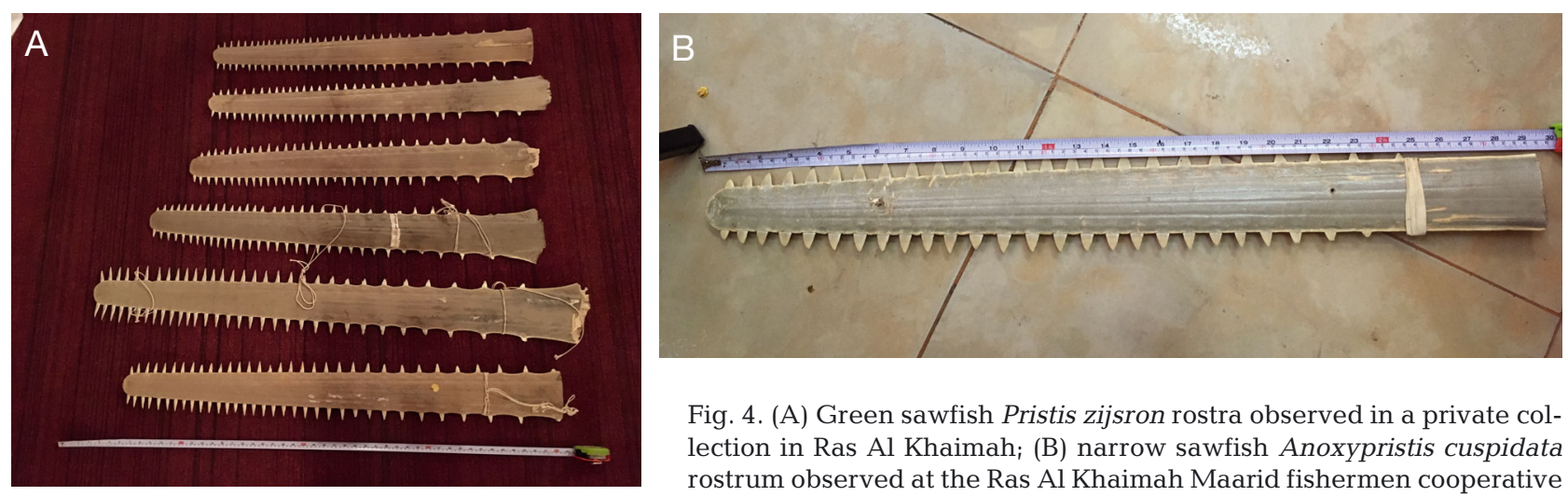

Fig. 4. (A) Green sawfish Pristis zijsron rostra observed in a private collection in Ras Al Khaimah; (B) narrow sawfish Anoxypristis cuspidata rostrum observed at the Ras Al Khaimah Maarid fishermen cooperative

Table 2. Details of sawfish rostra recorded during the study, with details of species, location sampled, total length of the rostrum, and number of teeth per side of saw (left and right)

\begin{tabular}{|c|c|c|c|c|c|}
\hline ID & Species & Location & $\begin{array}{l}\text { Rostrum } \\
\text { length }(\mathrm{cm})\end{array}$ & $\begin{array}{l}\text { No. of } \\
\text { teeth (left) }\end{array}$ & $\begin{array}{c}\text { No. of } \\
\text { teeth (right) }\end{array}$ \\
\hline 1 & Pristis zijsron & Abu Dhabi & 133 & 30 & 31 \\
\hline 2 & Pristis zijsron & Abu Dhabi & 98 & 33 & 35 \\
\hline 3 & Pristis zijsron & Abu Dhabi & 67 & 36 & 36 \\
\hline 4 & Pristis zijsron & Abu Dhabi & 115 & 34 & 33 \\
\hline 5 & Pristis zijsron & Abu Dhabi & 65 & 31 & 31 \\
\hline 6 & Pristis zijsron & Abu Dhabi & 96 & 36 & 36 \\
\hline 7 & Pristis zijsron & Abu Dhabi & 65 & 32 & 34 \\
\hline 8 & Pristis zijsron & Dubai & $76^{\mathrm{a}}$ & $22^{\mathrm{a}}$ & $22^{\mathrm{a}}$ \\
\hline 9 & Pristis zijsron & Fujairah & 96 & 35 & 35 \\
\hline 10 & Pristis zijsron & Fujairah & 103 & 35 & 34 \\
\hline 11 & Pristis zijsron & Ras Al Khaimah & 64 & 34 & 33 \\
\hline 12 & Pristis zijsron & Ras Al Khaimah & 82 & 31 & 29 \\
\hline 13 & Pristis zijsron & Ras Al Khaimah & 76 & 33 & 35 \\
\hline 14 & Pristis zijsron & Ras Al Khaimah & 125 & 31 & 32 \\
\hline 15 & Pristis zijsron & Ras Al Khaimah & 91 & 32 & 32 \\
\hline 16 & Pristis zijsron & Ras Al Khaimah & 92 & 34 & 33 \\
\hline 17 & Pristis zijsron & Ras Al Khaimah & 96 & 33 & 33 \\
\hline 18 & Pristis zijsron & Ras Al Khaimah & 86 & 30 & 31 \\
\hline 19 & $\begin{array}{c}\text { Anoxypristis } \\
\text { cuspidata }\end{array}$ & Ras Al Khaimah & 74 & 26 & 25 \\
\hline
\end{tabular}

with many populations showing alarming declines. Yet, fishers in the UAE emphasize that while sawfish numbers have severely declined, interactions with these animals still occur and there are locations where they can be encountered. The information reported here can therefore be used to focus research on sawfish in the UAE as well as the broader Arabian Gulf region, and to support the design of conservation and management measures to ensure their long-term survival.

Several studies have pointed to the fact that, in areas where sawfishes used to abound, many fishers are no longer able to immediately recognize pictures of sawfish or have never seen one (Robillard \& Séret 2006, Giglio et al. 2015, Leeney \& Poncelet 2015, Leeney 2016, Leeney \& Downing 2016, Reis-Filho et al. 2016). All fishers approached in the UAE were able to recognize the sawfish illustration presented, with a number of them stating

dataset for sawfish in UAE waters. Our results underscore the importance of using TEK as a tool to gather information on under-studied and threatened species and confirm that sawfish populations persist along the coast of the UAE. The use of TEK to document occurrence trends in sawfish has recently increased and has emphasized the disappearance of these species from various countries (Robillard \& Séret 2006, Giglio et al. 2015, Hossain et al. 2015, Leeney 2016, Reis-Filho et al. 2016). Other studies reviewing literature or investigating historical records (Moazzam \& Osmany 2014, Moore 2015, Leeney \& Downing 2016) also suggest that sawfish are facing increased threats, they had seen a sawfish in the few months prior to the interviews. While these encounters could have been questionable without photographic evidence, the fact that reports of green sawfish Pristis zijsron from the public (Gulf Elasmo Project unpubl. data) were also received during the same period suggests that these claims are reliable. These findings are in contrast to suggestions by Moore (2015), who stated that sawfish could be considered as largely functionally extinct from the Arabian Gulf ecosystem and close to being regionally extinct. In fact, interviews have been shown to be more reliable at providing information and valuable data about the status of 
sawfish than coastal fishery surveys and records from museums or management agencies (Seitz \& Poulakis 2002). Yet, it is clear that drastic declines in sawfish numbers have occurred. Almost all fishers stated that sawfish abundance had declined, with the majority pointing to the late 1990s and early 2000s as the time when these changes became apparent. The former distribution of sawfish in UAE waters was probably extensive in both waters of the Arabian Gulf and also extending into the Sea of Oman (Moore 2015). In fact, most fishers indicated locations where they were able to catch sawfish in the past in both coastal shallow water lagoons and in deeper waters along the whole coastline of the UAE. While this information cannot be used as an indicator of relative abundance of sawfish species in the region, it provides insight into previous distributions whilst highlighting the recent decline in sawfish abundance due to various threats.

Respondents perceived the main causes of decline in sawfish numbers to be overfishing and the use of nets in which sawfish easily become entangled. These threats correspond to those described in other parts of the world (Simpfendorfer 2000, 2013, Stevens et al. 2005, Dulvy et al. 2014, Giglio et al. 2015, Leeney \& Poncelet 2015, Leeney \& Downing 2016, Reis-Filho et al. 2016) and highlight the importance of reducing interactions of sawfish with fishing gear. However, $10 \%$ of fishers in this study also proposed the changes in coastal landscapes through large-scale developments, dredging, and reclamation (Sheppard et al. 2010) as a threat to these species and, as suggested by Peverell (2005), also believed that habitat loss had significantly contributed to their decline. These are the most plausible reasons for the reported declines, although due to a lack of long-term data on the species' abundance and distribution as a result of the scarcity of fisheries data, it is not possible to confirm the relative contribution of each of these factors.

Fishers in this study highlighted that sawfish use both shallow nearshore environments and offshore deep waters, with the highest numbers of sawfish generally encountered from February to May. They also suggested that the largest animals, presumably the adults, were usually found in deeper waters, while a range of sizes could be found in the coastal shallow areas. Encounter reports of the smalltooth sawfish $P$. pectinata in Florida also showed that adults were seen in both shallow and deep waters while juveniles were restricted to depths of less than $3 \mathrm{~m}$ of water (Seitz \& Poulakis 2002, Poulakis \& Seitz 2004). Although information on green sawfish movement and habitat use is limited, in Australia this spe- cies mainly occurs in inshore waters and has strong associations with mudflats and mangroves but can also occur in waters deeper than $70 \mathrm{~m}$ (Peverell \& Pillans 2004, Stevens et al. 2005, Simpfendorfer 2013). The occurrence period highlighted in our study could be due to the fact that interactions with fishing gear increase during those months with the UAE open net season that runs from mid-October to mid-April each year. However, fishers also mentioned that pearl divers had a name for this season because sawfish come closer inshore to give birth, which implies that these are likely to be the months when sawfish can be found in shallow coastal waters. Further research to determine which areas might be used by sawfish, including pupping and nursery grounds, is needed to ensure effective conservation planning, particularly in areas affected by anthropogenic processes (Morgan et al. 2015).

Additionally, respondents affirmed that specimens from a variety of sizes could be found in UAE waters, a fact that was further confirmed with the range of green sawfish rostra sizes encountered in private collections and the size range of specimens reported from the public (unpubl. data). This finding gives support to the premise that this region is likely to be a habitat for large juvenile and adult green sawfish and possibly also a breeding ground for the species. The fact that only 1 rostrum from the narrow sawfish Anoxypristis cuspidata was recorded suggests that green sawfish are relatively more abundant in this area. This also indicates that at least around the Strait of Hormuz, these 2 species have overlapping distributions. Fishers also mentioned that they could tell the difference between males and females from their rostra (shape and number of teeth). This could suggest that at some point in time, the narrow sawfish had a wider range or was more abundant in the area leading fishermen to believe the differences in rostra were sexual differences. However, several fishermen described how they targeted females to get eggs when they were pregnant but also to attract males to certain areas, similar to information reported by Brown (1990). These observations of male-female pairs have also been described by fishers in The Gambia and Mozambique (Leeney \& Downing 2016). This therefore confirms that fishers are able to identify differences between rostra and therefore the narrow sawfish is simply not as common in UAE waters, making it difficult to determine distribution and relative abundance of this species. Further research is warranted from the Iranian side of the Arabian Gulf to evaluate whether the narrow sawfish still occurs in this body of water or its current status. Also, further 
understanding of the life-history characteristics of the green sawfish, including growth, reproduction, and mortality, as well as investigations into the scale of their spatial and temporal movements in the Gulf is crucial to identify potential hotspots in areas where sawfish are still being sighted by fishers. This information on potential hotspots and habitat use is critical to assess the need for habitat protection and population recovery, and to focus research and conservation efforts (Simpfendorfer et al. 2008, Poulakis et al. 2011). This is particularly true for juvenile sawfish, with some studies (e.g. Poulakis et al. 2011) indicating that specific sites within nurseries are regularly used by certain species.

Unlike some tribal societies in Africa, Australia, and Central America, where sawfish are considered important in the cultural mythology (McDavitt 1996, Robillard \& Séret 2006, Leeney \& Poncelet 2015, Leeney \& Downing 2016), fishers here did not consider them symbolic or sacred. Yet, the fact that they had historical tales about these species and were able to describe traditional uses implies the cultural significance of sawfish to Emirati coastal communities. Each part of the sawfish is used, and the meat, eggs, and liver oil are highly regarded as a source of food and used in traditional dishes. Using this cultural connection is relevant in designing conservation action plans and creating a sense of stewardship in communities that will be involved in conservation activities.

Dulvy et al. (2014) highlighted that recovery of sawfish is possible and that viable populations currently exist in northern Australia and in the US (Florida) mainly due to strict protection of the species and their critical habitats. Sawfish have been protected in the UAE since 2008 (MOCCAE 2014), and according to fishers, the main remaining strongholds for them are in coastal shallow areas and the waters adjacent to Marine Protected Areas. However, to ensure the survival of these species and protect this remnant population, it is critical to increase awareness and develop outreach programs with fishers and other marine resource users to inform and educate them on the status of these species, encourage them to report encounters with these animals, and promote their safe handling and release. This is particularly important as studies suggest they can have high survival rates after being captured with a variety of gear (Wiley \& Simpfendorfer 2010). It is now also critical to locate areas where live sawfish can be found to assess which conservation efforts are mostly likely to be effective. One such tool could be the use of environmental DNA (eDNA) methods to test whether sawfishes can be detected (Simpfendorfer et al. 2016) in the various locations highlighted by fishers.

Given the small size of the Arabian Gulf, collaboration and information exchange with countries bordering this basin, as well as support from the international research and conservation communities, are essential to ensure the preservation and restoration of any remnant sawfish populations in this region. Genetic studies investigating the green sawfish in Australia emphasize that this species forms regional assemblages with little parental movement between populations (Phillips 2012). While the boundaries of these areas remain unknown, the implication is that local extinction will not be replenished by outside individuals and that it is critical to identify and manage these individual assemblages as independent populations (Phillips 2012). This is also supported by telemetry data, which suggests that sawfish movements tend to be less than $300 \mathrm{~km}$ from the shoreline (Peverell \& Pillans 2004, Simpfendorfer et al. 2011).

Finally, it is important to note that interview data have a certain level of bias as well as limitations associated with them (Seitz \& Poulakis 2002, Leeney \& Poncelet 2015, Leeney \& Downing 2016). While information collected here has provided a baseline for understanding the status of sawfishes in UAE waters, species-specific data and sex of specimens captured or sighted were mostly unavailable and there may have been inaccuracies in the respondents' memories of encounter dates and locations. Our sample size was lower than that in other studies using TEK to understand sawfishes (e.g. Hossain et al. 2015, Leeney \& Downing 2016). Yet, the consistency and high proportion of respondents recounting similar stories, uses, and locations lend credibility to the value of the information collected in this study. Furthermore, the use of encounter data has been shown to be effective in identifying the range and location of nursery areas as well as directing priority research areas (Seitz \& Poulakis 2002, Poulakis \& Seitz 2004, Poulakis et al. 2011, Norton et al. 2012). Therefore, data collected in this study, along with the location, seasonality, size ranges, and uses of sawfish in the UAE were useful for confirming that this Critically Endangered species is still present in UAE waters and that immediate actions are needed to secure its long-term survival.

Acknowledgements. We thank the fishermen who took the time to provide information on sawfish in the UAE. Many thanks to Ruth Leeney for providing information from her previous studies and advice on structuring interview questions. We also thank the management of the Environment Agency-Abu Dhabi for their support of our work. 


\section{LITERATURE CITED}

Brown JNB (1990) Sawfish. Emirates Nat Hist Group Bull 40:27

'D'Anastasi B, Simpfendorfer C, van Herwerden L (2013) Anoxypristis cuspidata. The IUCN Red List of Threatened Species 2013: e.T39389A18620409 (accessed 01 Aug 2016)

Dulvy NK, Fowler SL, Musick JA, Cavanagh RD and others (2014) Extinction risk and conservation of the world's sharks and rays. eLife 3:e00590

* Dulvy NK, Davidson LNK, Kyne PM, Simpfendorfer CA, Harrison LR, Carlson JK, Fordham SV (2016) Ghosts of the coast: global extinction risk and conservation of sawfishes. Aquat Conserv 26:134-153

Faria VV, McDavitt MT, Charvet P, Wiley TR, Simpfendorfer CA, Naylor GJP (2013) Species delineation and global population structure of Critically Endangered sawfishes (Pristidae). Zool J Linn Soc 167:136-164

Giglio VJ, Luiz OJ, Gerhardinger LC (2015) Depletion of marine megafauna and shifting baselines among artisanal fishers in eastern Brazil. Anim Conserv 18:348-358

Grandcourt E (2012) Reef fish and fisheries in the Gulf. In: Riegl BM, Purkis SJ (eds) Coral reefs of the Gulf: adaptation to climatic extremes, Vol 3. Springer, Dordrecht, p $127-161$

Hossain MA, Thompson BS, Chowdhury GW, Mohsanin S, Fahad ZH, Koldewey HJ, Islam MA (2015) Sawfish exploitation and status in Bangladesh. Aquat Conserv 25:781-799

Jabado RW, Al Ghais SM, Hamza W, Henderson AC (2015a) The shark fishery in the United Arab Emirates: an interview based approach to assess the status of sharks. Aquat Conserv 25:800-816

Jabado RW, Al Ghais SM, Hamza W, Henderson AC, Spaet JLY, Shivji MS, Hanner R (2015b) The trade in sharks and their products in the United Arab Emirates. Biol Conserv 181:190-198

Johannes RE, Freeman MMR, Hamilton RJ (2000) Ignore fishers' knowledge and miss the boat. Fish Fish 1:257-271

Leeney RH (2016) Fisher's ecological knowledge of sawfishes in Lake Piso, Liberia. Aquat Conserv 26:381-385

Leeney RH, Downing N (2016) Sawfishes in The Gambia and Senegal-shifting baselines over 40 years. Aquat Conserv 26:265-278

Leeney RH, Poncelet P (2015) Using fishers' ecological knowledge to assess the status and cultural importance of sawfishes in Guinea-Bissau. Aquat Conserv 25: 411-430

McDavitt MT (1996) The cultural and economic significance of sawfishes (family Pristidae). Shark News: Newsl IUCN Shark SG 8:10

Moazzam M, Osmany HB (2014) Occurrence of sawfish (Family Pristidae) in Pakistan. Int J Biol Biotechnol 11: 97-102

MOCCAE (Ministry of Climate Change and Environment) (2014) Decree 500 of 2014 on regulating the hunting of sharks in the United Arab Emirates. UAE Ministry of Climate Change and Environment. www.moccae.gov.ae

Moore ABM (2015) A review of sawfishes (Pristidae) in the Arabian region: diversity, distribution, and functional extinction of large and historically abundant marine vertebrates. Aquat Conserv 25:656-677

Morgan DL, Allen MG, Ebner BC, Whitty JM, Beatty SJ (2015) Discovery of a pupping site and nursery for criti- cally endangered green sawfish Pristis zijsron. J Fish Biol 86:1658-1663

Norton SL, Wiley TR, Carlson JK, Frick AL, Poulakis GR, Simpfendorfer CA (2012) Designating critical habitat for juvenile endangered smalltooth sawfish in the United States. Mar Coast Fish 4:473-480

Peverell SC (2005) Distribution of sawfishes (Pristidae) in the Queensland Gulf of Carpentaria, Australia, with notes on sawfish ecology. Environ Biol Fishes 73:391-402

Peverell SC (2009) Sawfish (Pristidae) of the Gulf of Carpentaria, Queensland, Australia. MSc thesis. James Cook University, Townsville

Peverell SC, Pillans RD (2004) Determining feasibility of acoustic tag attachment and documenting short-term movements in Pristis zijsron Bleeker, 1851. Report prepared for the National Oceans Office. Marine Fisheries Group, QDPI, Northern Fisheries Centre, Cairns

Phillips N (2012) Conservation genetics of Pristis sawfishes in Australian waters. PhD dissertation. Murdoch University, Perth

Poulakis GR, Seitz JC (2004) Recent occurrence of the smalltooth sawfish, Pristis pectinata (Elasmobranchiomorphi: Pristidae), in Florida Bay and the Florida Keys, with comments on sawfish ecology. Fla Sci 67:27-35

* Poulakis GR, Stevens PW, Timmers AA, Wiley TR, Simpfendorfer CA (2011) Abiotic affinities and spatiotemporal distribution of the endangered smalltooth sawfish, Pristis pectinata, in a south-western Florida nursery. Mar Freshw Res 62:1165-1177

* Reis-Filho JA, Freitas RHA, Loiola M, Leite L and others (2016) Traditional fisher perceptions on the regional disappearance of the largetooth sawfish Pristis pristis from the central coast of Brazil. Endang Species Res 29: 189-200

Robillard M, Séret B (2006) Cultural importance and decline of sawfish (Pristidae) populations in West Africa. Cybium 30:23-30

Sáenz-Arroyo A, Roberts CM, Torre J, Carino-Olvera M, Enriquez-Andrade RR (2005) Rapidly shifting environmental baselines among fishers of the Gulf of California. Proc R Soc B Biol Sci 272:1957-1962

Seitz JC, Poulakis GR (2002) Recent occurrence of sawfishes (Elasmobranchiomorphi: Pristidae) along the southwest coast of Florida (USA). Fla Sci 65:256-266

*Seitz JC, Poulakis GR (2006) Anthropogenic effects on the smalltooth sawfish (Pristis pectinata) in the United States. Mar Pollut Bull 52:1533-1540

* Sheppard C, Al-Husaini M, Al-Jamali F, Al-Yamani F and others (2010) The Gulf: a young sea in decline. Mar Pollut Bull 60:13-38

Simpfendorfer CA (2000) Predicting population recovery rates for endangered western Atlantic sawfishes using demographic analyses. Environ Biol Fishes 58:371-377

Simpfendorfer C (2013) Pristis zijsron. The IUCN Red List of Threatened Species 2013: e.T39393A18620401 (accessed 01 Aug 2016)

'Simpfendorfer CA, Poulakis GR, O'Donnell PM, Wiley TR (2008) Growth rates of juvenile smalltooth sawfish Pristis pectinata Latham in the western Atlantic. J Fish Biol 72: 711-723

Simpfendorfer CA, Yeiser BG, Wiley TR, Poulakis GR, Stevens PW, Heupel MR (2011) Environmental influences on the spatial ecology of juvenile smalltooth sawfish (Pristis pectinata): results from acoustic monitoring. PLOS ONE 6:e16918 
Simpfendorfer CA, Kyne PM, Noble TH, Goldsbury J and others (2016) Environmental DNA detects Critically Endangered largetooth sawfish in the wild. Endang Species Res 30:109-116

Stevens JD, Pillans RD, Salini JP (2005) Conservation assessment of Glyphis glyphis (speartooth shark), Glyphis garricki (northern river shark), Pristis microdon (freshwater sawfish) and Pristis zijsron (green sawfish). Report to Department of Environment and Heritage. CSIRO, Canberra. https://www.environment.gov. au/system/files/resources/d1696b5b-6a2e-4920-a3e2-16 e5a272349a/files/assessment-glyphis.pdf (accessed 10 Aug 2016)

Editorial responsibility: Gregg Poulakis (Guest Editor), Port Charlotte, Florida, USA
Stevens JD, McAuley RB, Simpfendorfer CA, Pillans RD (2008) Spatial distribution and habitat utilisation of sawfish (Pristis spp) in relation to fishing in northern Australia. A report to the Department of the Environment, Water, Heritage and the Arts. CSIRO and Western Australia Department of Fisheries. https://www.environment. gov.au/system/files/resources/d2b0bb03-401e-4e94-848f85458e4d7d1e/files/sawfish-report.pdf (accessed 10 Aug 2016)

Wiley TR, Simpfendorfer CA (2010) Using public encounter data to direct recovery efforts for the endangered smalltooth sawfish Pristis pectinata. Endang Species Res 12: 179-191

Submitted: August 31, 2016; Accepted: December 15, 2016 Proofs received from author(s): February 27, 2017 